\title{
Diabetes Mellitus Induces Alzheimer's Disease Pathology: Histopathological Evidence from Animal Models
}

\author{
Nobuyuki Kimura \\ Section of Cell Biology and Pathology, Department of Alzheimer's Disease Research, \\ Center for Development of Advanced Medicine for Dementia, National Center for Geriatrics and \\ Gerontology (NCGG), Gengo 35, Moriika, Obu, Aichi 474-8511, Japan; kimura@ncgg.go.jp; \\ Tel.: +81-562-44-5651 (ext. 6404); Fax: +81-562-46-8569 \\ Academic Editor: Toshiro Arai \\ Received: 25 February 2016; Accepted: 30 March 2016; Published: 5 April 2016
}

\begin{abstract}
Alzheimer's disease (AD) is the major causative disease of dementia and is characterized pathologically by the accumulation of senile plaques (SPs) and neurofibrillary tangles (NFTs) in the brain. Although genetic studies show that $\beta$-amyloid protein $(A \beta)$, the major component of SPs, is the key factor underlying AD pathogenesis, it remains unclear why advanced age often leads to AD. Interestingly, several epidemiological and clinical studies show that type II diabetes mellitus (DM) patients are more likely to exhibit increased susceptibility to AD. Moreover, growing evidence suggests that there are several connections between the neuropathology that underlies AD and DM, and there is evidence that the experimental induction of DM can cause cognitive dysfunction, even in rodent animal models. This mini-review summarizes histopathological evidence that DM induces AD pathology in animal models and discusses the possibility that aberrant insulin signaling is a key factor in the induction of AD pathology.
\end{abstract}

Keywords: Alzheimer's disease; animal model; diabetes mellitus; insulin resistance; pathology

\section{Introduction}

Alzheimer's disease (AD), the most common cause of dementia, is a progressive and fatal neurodegenerative disorder in which certain types of neurons in particular brain regions degenerate, resulting in severe neuronal loss. AD is characterized by two major pathological hallmarks: senile plaques (SPs) and neurofibrillary tangles (NFTs) [1-3]. This advancing pathology is believed to underlie the clinical presentation of memory deficiency first, followed by the steady loss of judgement, verbal fluency, reasoning skills, and other cognitive functions. SPs are the extracellular deposition of aggregated $\beta$-amyloid protein $(\mathrm{A} \beta)$. Enormous SP deposition occurs in the cortices of AD patients' brains, and this induces inflammatory responses via astroglial and microglial activation. Moreover, accumulating evidence suggests that $A \beta$ is causative for synaptic degeneration, eventually leading to cognitive dysfunction [4]. On the other hand, NFTs are the intracellular accumulation of aggregated tau, a microtubule-binding protein [5-8]. It is widely accepted that hyperphosphorylation of tau induces its aggregation, and the severity of NFT accumulation correlates well with neuronal loss and dementia in AD patients [8]. Although mutations in certain genes cause familial AD (FAD), more than $90 \%$ of AD patients have the sporadic type, suggesting that aging is the biggest risk factor for AD. While these molecular events are closely associated with the development of AD, lifestyle choices leading to adverse medical conditions are beginning to be understood as also contributing to AD development.

The chronic consumption of foods rich in saturated fats and sugar, accompanied by physical inactivity, causes insulin resistance and obesity, leading to a variety of metabolic disorders, such as 
metabolic syndrome and type II diabetes mellitus (DM) [9]. These metabolic diseases greatly reduce life expectancy and are associated with elevated blood pressure, cardiovascular disease, dyslipidemia, hypercholesterolemia, and proiflammatory states $[10,11]$. Recently, several epidemiological and clinical studies showed that type II DM patients are more likely to develop cognitive dysfunction and exhibit increased susceptibility to AD [12-17]. Recent findings also showed that there are several similarities and connections between the pathology observed in the brains of AD and DM patients. This is especially the case for aberrant insulin signaling, supporting the idea that AD can be thought of as "type III DM" [18-23]. In the brain, insulin plays a pivotal role in neuronal functions by regulating energy metabolism, growth, survival, and differentiation via insulin signaling [24-29]. Thus aberrant insulin signaling causes an alteration in the signaling pathway, leading to an AD-like pattern of reduced cerebral glucose metabolic rate in the brain [30,31]. Histopathological evidence supports this. The experimental induction of DM enhances AD pathology, such as SP and NFT development, in several animal models [32-43].

This mini-review summarizes the histopathological evidence that DM induces AD pathology in animal models. I also discuss the idea that aberrant insulin signaling could be the key factor that induces $\mathrm{AD}$ pathology.

\section{Diabetes Mellitus (DM) and $\beta$-Amyloid Protein (A $\beta)$ Pathology}

$\mathrm{A} \beta$, the major component of SP, is generated from $\beta$-amyloid precursor protein (APP) through sequential cleavages by $\beta$ - and $\gamma$-secretases $[4,44,45]$. Presenilin 1 (PS1) is the catalytic core of the $\gamma$-secretase complex, which is composed of anterior pharynx defective-1 (Aph-1), nicastrin, presenilin enhancer-2 (Pen-2), and PS1 or PS2 [46-49]. Mutations of PS1 are the predominant cause of FAD, as more than 200 mutations have been identified [50]. Some FAD-related mutations are also identified in APP itself [51]. Thus, many scientists take advantage of transgenic animal models that express FAD-related APP and/or PS1 mutants in the brain. Importantly, most FAD-related mutations selectively increase the production of longer $A \beta, A \beta 42$, which is prone to aggregate more readily than the dominant $A \beta 40$ species [52-54].

Accumulating evidence suggests that soluble $A \beta$ oligomers induce synaptic dysfunction, an early event in $\mathrm{AD}$ pathology. For example, $\mathrm{A} \beta$ oligomers perturb axonal transport of mitochondria and vesicles containing brain-derived neurotrophic factor (BDNF) [55-57]. Mitochondria and BDNF play crucial roles in synaptic transmission. At presynaptic boutons, mitochondria maintain neurotransmission by producing adenosine triphosphate and by buffering synaptic calcium [58-60]. After secretion from the presynaptic terminal, BDNF increases spine density by interacting with postsynaptic tropomyosin receptor kinase B receptors at the target cell membrane $[61,62]$. Thus, impaired axonal transport of mitochondria and BDNF can cause synaptic dysfunction $[63,64]$. At the postsynaptic membrane, $\mathrm{A} \beta$ oligomers interact with glutamate receptors and dysregulate calcium influx to impair long-term potentiation and enhance long-term depression [65-68]. $A \beta$ oligomers also alter spine morphology and decrease spine density $[69,70]$. These findings suggest that $\mathrm{A} \beta$ plays a pivotal role in $\mathrm{AD}$ pathogenesis, especially in synaptic degeneration. What is the connection between $\mathrm{DM}$ and $\mathrm{A} \beta$ pathology?

For DM studies, there are two established animal models. One is the streptozotocin (STZ)-induced type I DM model. STZ is a glucosamine-nitrosourea compound. After intraperitoneal injection of STZ, its metabolite has preferential cytotoxicity for $\beta$ cells in pancreatic islets, resulting in insulin deficiency. Several studies show that STZ-induced type I DM aggravates A $\beta$ pathology in the brains of APP transgenic mice, and it also increases $A \beta$ levels, even in the brains of non-transgenic rodents [37,71-74]. Devi et al. showed that $\beta$-secretase levels are increased in the brains of STZ-injected mice without any changes in mRNA [72]. This finding suggests that insulin deficiency affects post-translational modification of $\beta$-secretase and enhances the $\beta$-site cleavage of APP, leading to over-generation of $A \beta$ [72]. Intriguingly, previous studies showed that intracerebroventricular injection of STZ (icv-STZ) directly induces insulin deficiency in the brain and reproduces AD-like neurodegeneration 
in adult rats [75-78]. Moreover, icv-STZ also enhances A $\beta$ pathology in the brains of transgenic mice [34,79]. For example, icv-STZ induces intracellular accumulation of A $\beta$ oligomers accompanied by increased production of carboxy-terminal fragments from APP, the byproduct of $\gamma$-site cleavage [79]. These findings suggest that insulin deficiency could alter the activity of $\beta$ - and $\gamma$-secretases to enhance $\mathrm{A} \beta$ production $[72,79]$.

On the other hand, $A \beta$ clearance is also important for regulating $A \beta$ levels in the brain. There are several $A \beta$-degrading enzymes, such as neprilysin (NEP), endotherin-converting enzyme 1 (ECE-1), and insulin-degrading enzyme (IDE) [80-82]. In the brains of STZ-injected rats, ECE-1 levels are downregulated in both hippocampal and cortical regions, and IDE levels are also decreased in brain cortices [83]. Thus, insulin deficiency might induce $A \beta$ pathology through a combination of increased $\mathrm{A} \beta$ production and decreased $\mathrm{A} \beta$ clearance.

Rodents on a high-fat and/or sugar diet (HFD) represent the other established animal model for DM studies, especially for type II DM [9]. HFD not only can induce insulin resistance, but also enhances A $\beta$ pathology in several rodent models [32,42,84-86]. In APP transgenic mice, HFD increases the activity of $\gamma$-secretase in the brain and concomitantly decreases the activity of IDE, resulting in enhanced $A \beta$ accumulation in the brain [85]. These findings are consistent with those observed in type I DM models [72,79,83]. Spontaneous animal models, those in which human-like disease conditions occur naturally in animals, also confirm that DM induces $\mathrm{A} \beta$ pathology. In both BB/Wor rat (type I DM model) and BBZDR/Wor rat (type II DM model), APP, $\beta$-secretase, and A $\beta$ levels are all increased [87]. It is noteworthy that the type II DM model showed a much severe phenotype [87]. In another type II DM model, Otsuka Long-Evans Tokushima Fatty (OLETF) rats, A $\beta$ levels are also increased via downregulation of NEP [88]. These findings suggest that insulin resistance can induce A $\beta$ pathology, as well as insulin deficiency, and that aberrant insulin signaling is the likely key factor. One elegant genetic study showed that crossing an APP transgenic mouse or APP/PS1 knock-in mouse with diabetic mice (ob/ob, Nagoya-Shibata-Yasuda, or $\mathrm{db} / \mathrm{db}$ ) induces not only $\mathrm{A} \beta$ pathology but also a diabetic phenotype that shows aberrant insulin signaling [35]. This finding suggests that $A \beta$ itself may perturb insulin signaling.

Although it remains unclear why $\mathrm{A} \beta$ markedly accumulates in the brains of AD patients, endocytic pathology, like intraneuronal accumulation of abnormally enlarged endosomes, is frequently observed in the early stages of AD [89-93]. Our previous studies showed that endocytic pathology could be induced by aging alone, one that precedes SP formation in nonhuman primate brains $[94,95]$. Several studies show that both APP and $\beta$-secretase are transported intracellularly via endocytosis [96-98], and that A $\beta$ cleavage from APP mainly occurs in endosomes [70,71]. Moreover, recent genome-wide association studies have identified AD-associated variants in endocytosis-associated genes [99-103]. Therefore, perturbation of endocytosis is considered to be involved in $A \beta$ pathology. This is the line with results from our previous study demonstrating that endocytic disturbance significantly induces intracellular accumulation of $A \beta$ [97]. Recently, we found that type II DM induces $A \beta$ pathology in nonhuman primate brains accompanied by enhanced endocytic pathology, suggesting that type II DM aggravates age-related endocytic pathology in the brain [104]. Although additional studies are needed to clarify the precise mechanism, aberrant insulin signaling may alter intracellular endosome trafficking, leading to enhanced $A \beta$ accumulation in the brain. Evidently, SorCS1, which is genetically associated with DM, is involved in intracellular trafficking of APP [105]. Taken together, aberrant insulin signaling might be the key factor in the induction of $A \beta$ pathology via alteration of $A \beta$ metabolism (Figure 1). 


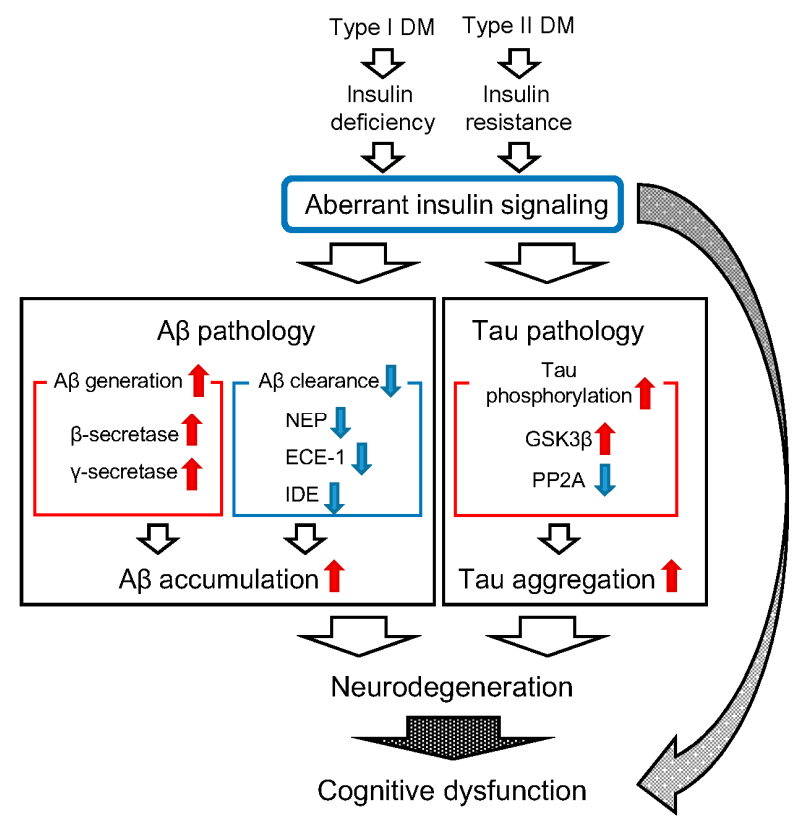

Figure 1. Hypothetical model illustrating the idea that diabetes mellitus induces Alzheimer's disease (AD) pathology and cognitive dysfunction. Both type I and type II diabetes mellitus (DM) eventually cause aberrant insulin signaling. Histopathological evidence in animal model studies suggest that DM aggravates both $\beta$-amyloid protein $(\mathrm{A} \beta)$ and tau pathology via aberrant insulin signaling, leading to neurodegeneration. Several studies show that aberrant insulin signaling also causes cognitive dysfunction by itself. That may be why DM patients exhibit greater susceptibility toward developing AD. Modification of the insulin signaling pathway may be a promising therapeutic target for preventing cognitive dysfunction in DM and AD patients. Red arrow, increase or upregulation; blue arrow, decrease or downregulation.

\section{DM and Tau Pathology}

Although FAD-related genes are associated with $\mathrm{A} \beta$, the degree of dementia in AD patients and the neuronal loss correlates well with tau pathology in their brains [106]. Tau, a microtubule-associated protein, is the major component of NFTs, and hyperphosphorylation of tau is considered to be responsible for its aggregation [5-8].

One of the most relevant protein kinases involved in tau phosphorylation is glycogen synthase kinase $3 \beta$ (GSK3 $\beta$ ) [107-111]. Insulin and insulin-like growth factors (IGFs) mediate intracellular signaling pathways via binding to insulin receptor (IR), leading to its autophosphorylation and activation [112-114]. IR tyrosine kinases phosphorylate IR substrate (IRS) molecules, resulting in the activation of phosphoinositide-3 kinase (PI3K)/Akt signaling [115-118]. Importantly, the activation of the PI3K/Akt pathway results in the phosphorylation of Ser9 of GSK3 $\beta$ and inhibition of its kinase activity [119]. Thus, insulin deficiency/resistance can induce abnormal activation of GSK3 $\beta$. Several studies show that the activity of GSK3 $\beta$ is enhanced in both type I and type II DM models, leading to the accumulation of hyperphosphorylated tau [30,32,34,71,120].

The activity of protein phosphatases is also important in mediating tau phosphorylation level, and the activity of certain protein phosphatases, such as protein phosphatase 2A (PP2A), is clearly decreased in AD brains [121-124]. Several studies show that DM dysregulates PP2A activity in several animal models [125-127]. These findings suggest that aberrant insulin signaling can alter both GSK3 $\beta$ and PP2A activities, leading to hyperphosphorylation of tau (Figure 1). 


\section{Conclusions}

Animal model studies suggest that both type I and type II DM can aggravate AD pathology, and that aberrant insulin signaling may be the key factor (Figure 1). This is a reasonable idea, bolstered by the finding that insulin treatment ameliorates AD pathology in the brains of AD model mice [84,128]. Moreover, insulin signaling-related genes, such as IR, IRS1, IRS2, IGF1, IGF2, and IGFR, are decreased in APP/PS1 knock-in mice, suggesting that AD-related genes also affect insulin signaling by themselves [129]. Strikingly, recent findings show that a clinical trial of intranasal insulin treatment improves cognitive function of patients with AD and those in the predrome stage, mild cognitive impairment (MCI) [130,131]. Thus, modification of the insulin signaling pathway may be a promising strategy for preventing cognitive decline of patients with type II DM, MCI, and even AD.

Acknowledgments: This study was supported by the Research Funding for Longevity Sciences (25-20) from the National Center for Geriatrics and Gerontology (NCGG), Japan.

Author Contributions: Nobuyuki Kimura wrote the whole manuscript.

Conflicts of Interest: The authors declare no conflict of interest.

\section{References}

1. Selkoe, D.J. The molecular pathology of Alzheimer's disease. Neuron 1991, 6, 487-498. [CrossRef]

2. Mattson, M.P. Pathway towards and away from Alzheimer's disease. Nature 2004, 430, 631-639. [CrossRef] [PubMed]

3. Armstrong, R.A. The molecular biology of senile plaques and neurofibrillary tangles in Alzheimer's disease. Folia Neuropathol. 2009, 47, 289-299. [PubMed]

4. Hardy, J.; Selkoe, D.J. The amyloid hypothesis of Alzheimer's disease: Progress and problems on the road to therapeutics. Science 2002, 297, 353-356. [CrossRef] [PubMed]

5. Cross, D.; Vial, C.; Maccioni, R.B. A tau-like protein interacts with stress fibers and microtubules in human and rodent cultured cell lines. J. Cell Sci. 1993, 105, 51-60. [PubMed]

6. Kosik, K.S.; Joachim, C.L.; Selkoe, D.J. Microtubule-associated protein tau is a major antigenic component of paired helical filaments in Alzheimer disease. PNAS 1986, 83, 4044-4048. [CrossRef] [PubMed]

7. Maccioni, R.B.; Cambiazo, V. Role of microtubule-associated proteins in the control of microtubule assembly. Physiol. Rev. 1995, 75, 835-864. [PubMed]

8. Mandelkow, E.M.; Biernat, J.; Drewes, G.; Gustke, N.; Trinczek, B.; Mandelkow, E. Tau domains, phosphorylation, and interactions with microtubules. Neurobiol. Aging 1995, 16, 355-363. [CrossRef]

9. Kraegen, E.W.; Clark, P.W.; Jenkins, A.B.; Daley, E.A.; Chisholm, D.J.; Storlien, L.H. Development of muscle insulin resistance after liver insulin resistance in high-fat-fed rats. Diabetes 1991, 40, 1397-1403. [CrossRef] [PubMed]

10. Lind, L.; Lithell, H. Hypertension, hyperlipidemia, insulin resistance and obesity: Parts of a metabolic syndrome. Blood Press. Suppl. 1992, 4, 49-54. [PubMed]

11. Meigs, J.B. Invited commentary: Insulin resistance syndrome? Syndrome X? Multiple metabolic syndrom? A syndrome at all? Factor analysis reveals patterns in the fabric of correlated metabolic risk factors. Am. J. Epidemiol. 2000, 152, 908-911. [CrossRef] [PubMed]

12. Leibson, C.L.; Rocca, W.A.; Hanson, V.A.; Cha, R.; Kokmen, E.; O’Brien, P.C.; Palumbo, P.J. Risk of dementia among persons with diabetes mellitus: A population-based cohort study. Am. J. Epidemiol. 1997, 145, 301-308. [CrossRef] [PubMed]

13. Arvanitakis, Z.; Wilson, R.S.; Bienias, J.L.; Evans, D.A.; Bennett, D.A. Diabetes mellitus and risk of Alzheimer disease and decline in cognitive function. Arch. Neurol. 2004, 61, 661-666. [CrossRef] [PubMed]

14. Frisardi, V.; Solfrizzi, V.; Seripa, D.; Capurso, C.; Santamato, A.; Sancarlo, D.; Vendemiale, G.; Pilotto, A.; Panza, F. Metabolic-cognitive syndrome: A cross-talk between metabolic syndrome and Alzheimer's disease. Ageing Res. Rev. 2010, 9, 399-417. [CrossRef] [PubMed]

15. Daviglus, M.L.; Plassman, B.L.; Pirzada, A.; Bell, C.C.; Bowen, P.E.; Burke, J.R.; Connolly, E.S., Jr.; Dunbar-Jacob, J.M.; Granieri, E.C.; McGarry, K.; et al. Risk factors and preventive interventions for Alzheimer disease: State of the science. Arch. Neurol. 2011, 68, 1185-1190. [CrossRef] [PubMed] 
16. Crane, P.K.; Walker, R.; Hubbard, R.A.; Li, G.; Nathan, D.M.; Zheng, H.; Haneuse, S.; Craft, S.; Montine, T.J.; Kahn, S.E.; et al. Glucose levels and risk of dementia. N. Engl. J. Med. 2013, 369, 540-548. [CrossRef] [PubMed]

17. Ott, A.; Stolk, R.P.; van Harskamp, F.; Pols, H.A.P.; Hofman, A.; Breteler, M.M.B. Diabetes mellitus and the risk of dementia: The Rotterdam Study. Neurology 1999, 53, 1937-1942. [CrossRef] [PubMed]

18. Convit, A.; Wolf, O.T.; Tarshish, C.; de Leon, M.J. Reduced glucose tolerance is associated with poor memory performance and hippocampal atrophy among normal elderly. PNAS 2003, 100, 2019-2022. [CrossRef] [PubMed]

19. Steen, E.; Terry, B.M.; Rivera, E.J.; Cannon, J.L.; Neely, T.R.; Tavares, R.; Xu, X.J.; Wands, J.R.; de la Monte, S.M. Impaired insulin and insulin-like growth factor expression and signaling mechanisms in Alzheimer's disease-Is this type 3 diabetes? J. Alzheimers Dis. 2005, 7, 63-80. [PubMed]

20. Rönnemaa, E.; Zethelius, B.; Sundelöf, J.; Sundström, J.; Degerman-Gunnarsson, M.; Berne, C.; Lannfelt, L.; Kilander, L. Impaired insulin secretion increases the risk of Alzheimer disease. Neurology 2008, 71, 1065-1071. [CrossRef] [PubMed]

21. Panza, F.; Frisardi, V.; Capurso, C.; Imbimbo, B.P.; Vendemiale, G.; Santamato, A.; D’Onofrio, G.; Seripa, D.; Sancarlo, D.; Pilotto, A.; et al. Metabolic syndrome and cognitive impairment: Current epidemiology and possible underlying mechanisms. J. Alzheimers Dis. 2010, 21, 691-724. [PubMed]

22. Ohara, T.; Doi, Y.; Ninomiya, T.; Hirakawa, Y.; Hata, J.; Iwaki, T.; Kanba, S.; Kiyohara, Y. Glucose tolerance status and risk of dementia in the community: The Hisayama study. Neurology 2011, 77, 1126-1134. [CrossRef] [PubMed]

23. De Felice, F.G.; Ferreira, S.T. Inflammation, defective insulin signaling, and mitochondrial dysfunction as common molecular denominators connecting type 2 diabetes to Alzheimer disease. Diabetes 2014, 63, 2262-2272. [CrossRef] [PubMed]

24. Lacroix, M.C.; Badonnel, K.; Meunier, N.; Tan, F.; Schlegel-Le Poupon, C.; Durieux, D.; Monnerie, R.; Baly, C.; Congar, P.; Salesse, R.; et al. Expression of insulin system in the olfactory epithelium: First approaches to its role and regulation. J. Neuroendocrinol. 2008, 20, 1176-1190. [CrossRef] [PubMed]

25. Kuwabara, T.; Kagalwala, M.N.; Onuma, Y.; Ito, Y.; Warashina, M.; Terashima, K.; Sanosaka, T.; Nakashima, K.; Gage, F.H.; Asashima, M. Insulin biosynthesis in neuronal progenitors derived from adult hippocampus and the olfactory bulb. EMBO Mol. Med. 2011, 3, 742-754. [CrossRef] [PubMed]

26. Bingham, E.M.; Hopkins, D.; Smith, D.; Pernet, A.; Hallett, W.; Reed, L.; Marsden, P.K.; Amiel, S.A. The role of insulin in human brain glucose metabolism: An 18 fluoro-deoxyglucose positron emission tomography study. Diabetes 2002, 51, 3384-3390. [CrossRef] [PubMed]

27. Zhao, W.Q.; Chen, H.; Quon, M.J.; Alkon, D.L. Insulin and the insulin receptor in experimental models of learning and memory. Eur. J. Pharmacol. 2004, 490, 71-81. [CrossRef] [PubMed]

28. Huang, T.J.; Verkhratsky, A.; Fernyhough, P. Insulin enhances mitochondrial inner membrane potential and increases ATP levels through phosphoinositide 3-kinase in adult sensory neurons. Mol. Cell. Neurosci. 2005, 28, 42-54. [CrossRef] [PubMed]

29. Duarte, A.I.; Proença, T.; Oliveira, C.R.; Santos, M.S.; Rego, A.C. Insulin restores metabolic function in cultured cortical neurons subjected to oxidative stress. Diabetes 2006, 55, 2863-2870. [CrossRef] [PubMed]

30. Salkovic-Petrisic, M.; Tribl, F.; Schmidt, M.; Hoyer, S.; Riederer, P. Alzheimer-like changes in protein kinase B and glycogen synthase kinase-3 in rat frontal cortex and hippocampus after damage to the insulin signalling pathway. J. Neurochem. 2006, 96, 1005-1015. [CrossRef] [PubMed]

31. Baker, L.D.; Cross, D.J.; Minoshima, S.; Belongia, D.; Watson, G.S.; Craft, S. Insulin resistance and Alzheimer-like reductions in regional cerebral glucose metabolism for cognitively normal adults with prediabetes or early type 2 diabetes. Arch. Neurol. 2010, 68, 51-57. [CrossRef] [PubMed]

32. Ho, L.; Qin, W.; Pompl, P.N.; Xiang, Z.; Wang, J.; Zhao, Z.; Peng, Y.; Cambareri, G.; Rocher, A.; Mobbs, C.V.; et al. Diet-induced insulin resistance promotes amyloidosis in a transgenic mouse model of Alzheimer's disease. FASEB J. 2004, 18, 902-904. [CrossRef] [PubMed]

33. Li, Y.; Duffy, K.B.; Ottinger, M.A.; Ray, B.; Bailey, J.A.; Holloway, H.W.; Tweedie, D.; Perry, T.; Mattson, M.P.; Kapogiannis, D.; et al. GLP-1 receptor stimulation reduces amyloid- $\beta$ peptide accumulation and cytotoxicity in cellular and animal models of Alzheimer's disease. J. Alzheimers Dis. 2010, 19, 1205-1219. [PubMed] 
34. Plaschke, K.; Kopitz, J.; Siegelin, M.; Schliebs, R.; Salkovic-Petrisic, M.; Riederer, P.; Hoyer, S. Insulin-resistant brain state after intracerebroventricular streptozotocin injection exacerbates Alzheimer-like changes in Tg2576 A $\beta$ PP-overexpressing mice. J. Alzheimers Dis. 2010, 19, 691-704. [PubMed]

35. Takeda, S.; Sato, N.; Uchio-Yamada, K.; Sawada, K.; Kunieda, T.; Takeuchi, D.; Kurinami, H.; Shinohara, M.; Rakugi, H.; Morishita, R. Diabetes-accelerated memory dysfunction via cerebrovascular inflammation and $A \beta$ deposition in an Alzheimer mouse model with diabetes. PNAS 2010, 107, 7036-7041. [CrossRef] [PubMed]

36. Bitela, C.L.; Kasinathanb, C.; Kaswalab, R.H.; Klein, W.L.; Frederiksea, P.H. Amyloid- $\beta$ and Tau Pathology of Alzheimer's Disease Induced by Diabetes in a Rabbit Animal Model. J. Alzheimers Dis. 2012, 32, 291-305.

37. Currais, A.; Prior, M.; Lo, D.; Jolivalt, C.; Schubert, D.; Maher, P. Diabetes exacerbates amyloid and neurovascular pathology in aging-accelerated mice. Aging Cell 2012, 11, 1017-1026. [CrossRef] [PubMed]

38. Maesako, M.; Uemura, K.; Kubota, M.; Kuzuya, A.; Sasaki, K.; Asada, M.; Watanabe, K.; Hayashida, N.; Ihara, M.; Ito, H.; et al. Environmental enrichment ameliorated high-fat diet-induced A $\beta$ deposition and memory deficit in APP transgenic mice. Neurobiol. Aging 2012, 33, 1011.e11-1011.e23. [CrossRef] [PubMed]

39. Son, S.M.; Song, H.; Byun, J.; Park, K.S.; Jang, H.C.; Park, Y.J.; Mook-Jung, I. Accumulation of autophagosomes contributes to enhanced amyloidogenic APP processing under insulin-resistant conditions. Autophagy 2012, 8, 1842-1844. [CrossRef] [PubMed]

40. Yamamoto, N.; Matsubara, T.; Sobue, K.; Tanida, M.; Kasahara, R.; Naruse, K.; Taniura, H.; Sato, T.; Suzuki, K. Brain insulin resistance accelerates A $\beta$ fibrillogenesis by inducing GM1 ganglioside clustering in the presynaptic membranes. J. Neurochem. 2012, 121, 619-628. [CrossRef] [PubMed]

41. Chen, Y.; Liang, Z.; Blanchard, J.; Dai, C.L.; Sun, S.; Lee, M.H.; Grundke-Iqbal, I.; Iqbal, K.; Liu, F.; Gong, C.X. A non-transgenic mouse model (icv-STZ mouse) of Alzheimer's disease: Similarities to and differences from the transgenic model (3xTg-AD mouse). Mol. Neurobiol. 2013, 47, 711-725. [CrossRef] [PubMed]

42. Yang, Y.; Wu, Y.; Zhang, S.; Song, W. High glucose promotes A $\beta$ production by inhibiting APP degradation. PLoS ONE 2013, 8, e69824. [CrossRef] [PubMed]

43. Mehlaa, J.; Chauhanc, B.C.; Chauhana, N.B. Experimental Induction of Type 2 Diabetes in Aging-Accelerated Mice Triggered Alzheimer-Like Pathology and Memory Deficits. J. Alzheimers Dis. 2014, 39, 145-162.

44. Vassar, R.; Bennett, B.D.; Babu-Khan, S.; Kahn, S.; Mendiaz, E.A.; Denis, P.; Teplow, D.B.; Ross, S.; Amarante, P.; Loeloffs, R.; et al. $\beta$-Secretase cleavage of Alzheimer's amyloid precursor protein by the transmembrane aspartic protease BACE. Science 1999, 286, 735-741. [CrossRef] [PubMed]

45. Sisodia, S.S.; St George-Hyslop, P.H. Gamma-Secretase, Notch, A $\beta$ and Alzheimer's disease: Where do the presenilins fit in? Nat. Rev. Neurosci. 2002, 3, 281-290. [CrossRef] [PubMed]

46. Li, Y.M.; Lai, M.T.; Xu, M.; Huang, Q.; DiMuzio-Mower, J.; Sardana, M.K.; Shi, X.P.; Yin, K.C.; Shafer, J.A.; Gardell, S.J. Presenilin 1 is linked with $\gamma$-secretase activity in the detergent solubilized state. PNAS 2000, 97, 6138-6143. [CrossRef] [PubMed]

47. Yu, G.; Nishimura, M.; Arakawa, S.; Levitan, D.; Zhang, L.; Tandon, A.; Song, Y.Q.; Rogaeva, E.; Chen, F.; Kawarai, T.; et al. Nicastrin modulates presenilin-mediated notch $/ g l p-1$ signal transduction and $\beta$ APP processing. Nature 2000, 407, 48-54. [PubMed]

48. Francis, R.; McGrath, G.; Zhang, J.; Ruddy, D.A.; Sym, M.; Apfeld, J.; Nicoll, M.; Maxwell, M.; Hai, B.; Ellis, M.C.; et al. Aph-1 and pen-2 are required for Notch pathway signaling, $\gamma$-secretase cleavage of $\beta$ APP, and presenilin protein accumulation. Dev. Cell 2000, 3, 85-97. [CrossRef]

49. Goutte, C.; Tsunozaki, M.; Hale, V.A.; Priess, J.R. APH-1 is a multipass membrane protein essential for the Notch signaling pathway in Caenorhabditis elegans embryos. PNAS 2002, 99, 775-779. [CrossRef] [PubMed]

50. Sherrington, R.; Rogaev, E.I.; Liang, Y.; Rogaeva, E.A.; Levesque, G.; Ikeda, M.; Chi, H.; Lin, C.; Li, G.; Holman, K.; et al. Cloning of a gene bearing missense mutations in early-onset familial Alzheimer's disease. Nature 1995, 375, 754-760. [CrossRef] [PubMed]

51. Hardy, J. Amyloid, the presenilins and Alzheimer's disease. Trends Neurosci. 1997, 20, 154-159. [CrossRef]

52. Borchelt, D.R.; Thinakaran, G.; Eckman, C.B.; Lee, M.K.; Davenport, F.; Ratovitsky, T.; Prada, C.M.; Kim, G.; Seekins, S.; Yager, D.; et al. Familial Alzheimer's disease-linked presenilin 1 variants elevate A $\beta 1-42 / 1-40$ ratio in vitro and in vivo. Neuron 1996, 17, 1005-1013. [CrossRef]

53. Duff, K.; Eckman, C.B.; Zehr, C.; Yu, X.; Prada, C.M.; Perez-tur, J.; Hutton, M.; Buee, L.; Harigaya, Y.; Yager, D.; et al. Increased amyloid- $\beta 42(43)$ in brains of mice expressing mutant presenilin 1 . Nature 1996, 383, 710-713. [CrossRef] [PubMed] 
54. Scheuner, D.; Eckman, C.B.; Jensen, M.; Song, X.; Citron, M.; Suzuki, N.; Bird, T.D.; Hardy, J.; Hutton, M.; Kukull, W.; et al. Secreted amyloid $\beta$-protein similar to that in the senile plaques of Alzheimer's disease is increased in vivo by the presenilin 1 and 2 and APP mutations linked to familial Alzheimer's disease. Nat. Med. 1996, 2, 864-870. [CrossRef] [PubMed]

55. Decker, H.; Lo, K.Y.; Unger, S.M.; Ferreira, S.T.; Silverman, M.A. Amyloid- $\beta$ peptide oligomers disrupt axonal transport through an NMDA receptordependent mechanism that is mediated by glycogen synthase kinase $3 \beta$ in primary cultured hippocampal neurons. J. Neurosci. 2010, 30, 9166-9171. [CrossRef] [PubMed]

56. Vossel, K.A.; Zhang, K.; Brodbeck, J.; Daub, A.C.; Sharma, P.; Finkbeiner, S.; Cui, B.; Mucke, L. Tau reduction prevents A $\beta$-induced defects in axonal transport. Science 2010, 330, 198. [CrossRef] [PubMed]

57. Tang, Y.; Scott, D.A.; Das, U.; Edland, S.D.; Radomski, K.; Koo, E.H.; Roy, S. Early and selective impairments in axonal transport kinetics of synaptic cargoes induced by soluble amyloid $\beta$-protein oligomers. Traffic 2012, 13, 681-693. [CrossRef] [PubMed]

58. Li, Z.; Okamoto, K.; Hayashi, Y.; Sheng, M. The importance of dendritic mitochondria in the morphogenesis and plasticity of spines and synapses. Cell 2004, 119, 873-887. [CrossRef] [PubMed]

59. Sheng, Z.H.; Cai, Q. Mitochondrial transport in neurons: Impact on synaptic homeostasis and neurodegeneration. Nat. Rev. Neurosci. 2012, 13, 77-93. [CrossRef] [PubMed]

60. Sheng, Z.H. Mitochondrial trafficking and anchoring in neurons: New insight and implications. J. Cell Biol. 2014, 204, 1087-1098. [CrossRef] [PubMed]

61. Luine, V.; Frankfurt, M. Interactions between estradiol, BDNF and dendritic spines in promoting memory. Neuroscience 2012, 239, 34-45. [CrossRef] [PubMed]

62. Kellner, Y.; Gödecke, N.; Dierkes, T.; Thieme, N.; Zagrebelsky, M.; Korte, M. The BDNF effects on dendritic spines of mature hippocampal neurons depend on neuronal activity. Front. Synaptic Neurosci. 2014, 6, 5. [CrossRef] [PubMed]

63. Scharfman, H.E.; Chao, M.V. The entorhinal cortex and neurotrophin signaling in Alzheimer's disease and other disorders. Cogn. Neurosci. 2013, 4, 123-135. [CrossRef] [PubMed]

64. Khatri, N.; Man, H.Y. Synaptic activity and bioenergy homeostasis: Implications in brain trauma and neurodegenerative diseases. Front. Neurol. 2013, 4, 199. [CrossRef] [PubMed]

65. Lambert, M.P.; Barlow, A.K.; Chromy, B.A.; Edwards, C.; Freed, R.; Liosatos, M.; Morgan, T.E.; Rozovsky, I.; Trommer, B.; Viola, K.L.; et al. Diffusible, nonfibrillar ligands derived from A $\beta_{1-42}$ are potent central nervous system neurotoxins. PNAS 1998, 95, 6448-6453. [CrossRef] [PubMed]

66. Walsh, D.M.; Klyubin, I.; Fadeeva, J.V.; Cullen, W.K.; Anwyl, R.; Wolfe, M.S.; Rowan, M.J.; Selkoe, D.J. Naturally secreted oligomers of amyloid $\beta$ protein potently inhibit hippocampal long-term potentiation in vivo. Nature 2002, 416, 535-539. [CrossRef] [PubMed]

67. Shankar, G.M.; Li, S.; Mehta, T.H.; Garcia-Munoz, A.; Shepardson, N.E.; Smith, I.; Brett, F.M.; Farrell, M.A.; Rowan, M.J.; Lemere, C.A.; et al. Amyloid- $\beta$ protein dimers isolated directly from Alzheimer's brains impair synaptic plasticity and memory. Nat. Med. 2008, 14, 837-842. [CrossRef] [PubMed]

68. Li, S.; Hong, S.; Shepardson, N.E.; Walsh, D.M.; Shankar, G.M.; Selkoe, D. Soluble oligomers of amyloid $\beta$ protein facilitate hippocampal long-term depression by disrupting neuronal glutamate uptake. Neuron 2009, 62, 788-801. [CrossRef] [PubMed]

69. Lacor, P.N.; Buniel, M.C.; Furlow, P.W.; Clemente, A.S.; Velasco, P.T.; Wood, M.; Viola, K.L.; Klein, W.L. $\mathrm{A} \beta$ oligomer-induced aberrations in synapse composition, shape, and density provide a molecular basis for loss of connectivity in Alzheimer's disease. J. Neurosci. 2007, 27, 796-807. [CrossRef] [PubMed]

70. Shankar, G.M.; Bloodgood, B.L.; Townsend, M.; Walsh, D.M.; Selkoe, D.J.; Sabatini, B.L. Natural oligomers of the Alzheimer amyloid- $\beta$ protein induce reversible synapse loss by modulating an NMDA-type glutamate receptor-dependent signaling pathway. J. Neurosci. 2007, 27, 2866-2875. [CrossRef] [PubMed]

71. Jolivalt, C.G.; Hurford, R.; Lee, C.A.; Dumaop, W.; Rockenstein, E.; Masliah, E. Type 1 diabetes exaggerates features of Alzheimer's disease in APP transgenic mice. Exp. Neurol. 2010, 223, 22-31. [CrossRef] [PubMed]

72. Devi, L.; Alldred, M.J.; Ginsberg, S.D.; Ohno, M. Mechanisms underlying insulin deficiency-induced acceleration of $\beta$-amyloidosis in a mouse model of Alzheimer's disease. PLoS ONE 2012, 7, e32792. [CrossRef] [PubMed]

73. Liu, Y.; Liu, H.; Yang, J.; Liu, X.; Lu, S.; Wen, T.; Xie, L.; Wang, G. Increased amyloid $\beta$-peptide (1-40) level in brain of streptozotocin-induced diabetic rats. Neuroscience 2008, 153, 796-802. [CrossRef] [PubMed] 
74. Wang, J.Q.; Yin, J.; Song, Y.F.; Zhang, L.; Ren, Y.X.; Wang, D.G.; Gao, L.P.; Jing, Y.H. Brain aging and AD-like pathology in streptozotocin-induced diabetic rats. J. Diabetes Res. 2014, 2014, 796840. [CrossRef] [PubMed]

75. Plaschke, K.; Hoyer, S. Action of the diabetogenic drug streptozotocin on glycolytic and glycogenolytic metabolism in adult rat brain cortex and hippocampus. Int. J. Dev. Neurosci. 1993, 11, 477-483. [CrossRef]

76. Duelli, R.; Schröck, H.; Kuschinsky, W.; Hoyer, S. Intracerebroventricular injection of streptozotocin induces discrete local changes in cerebral glucose utilization in rats. Int. J. Dev. Neurosci. 1994, 12, 737-743. [CrossRef]

77. Hoyer, S.; Müller, D.; Plaschke, K. Desensitization of brain insulin receptor. Effect on glucose/energy and related metabolism. J. Neural Transm. Suppl. 1994, 44, 259-268. [PubMed]

78. Lannert, H.; Hoyer, S. Intracerebroventricular administration of streptozotocin causes long-term diminutions in learning and memory abilities and in cerebral energy metabolism in adult rats. Behav. Neurosci. 1998, 112, 1199-1208. [CrossRef] [PubMed]

79. Lin, F.; Jia, J.; Qin, W. Enhancement of $\beta$-amyloid oligomer accumulation after intracerebroventricular injection of streptozotocin, which involves central insulin signaling in a transgenic mouse model. Neuroreport 2014, 25, 1289-1295. [CrossRef] [PubMed]

80. Iwata, N.; Tsubuki, S.; Takaki, Y.; Watanabe, K.; Sekiguchi, M.; Hosoki, E.; Kawashima-Morishima, M.; Lee, H.J.; Hama, E.; Sekine-Aizawa, Y.; et al. Identification of the major A $\beta_{1-42}$-degrading catabolic pathway in brain parenchyma: Suppression leads to biochemical and pathological deposition. Nat. Med. 2000, 6, 143-150. [CrossRef] [PubMed]

81. Eckman, E.A.; Reed, D.K.; Eckman, C.B. Degradation of the Alzheimer's amyloid $\beta$ peptide by endothelin-converting enzyme. J. Biol. Chem. 2001, 276, 24540-24548. [CrossRef] [PubMed]

82. Qiu, W.Q.; Walsh, D.M.; Ye, Z.; Vekrellis, K.; Zhang, J.; Podlisny, M.B.; Rosner, M.R.; Safavi, A.; Hersh, L.B.; Selkoe, D.J. Insulin-degrading enzyme regulates extracellular levels of amyloid $\beta$-protein by degradation. J. Biol. Chem. 1998, 273, 32730-32738. [CrossRef] [PubMed]

83. Liu, Y.; Liu, L.; Lu, S.; Wang, D.; Liu, X.; Xie, L.; Wang, G. Impaired amyloid $\beta$-degrading enzymes in brain of streptozotocin-induced diabetic rats. J. Endocrinol. Investig. 2011, 34, 26-31. [CrossRef]

84. Vandal, M.; White, P.J.; Tremblay, C.; St-Amour, I.; Chevrier, G.; Emond, V.; Lefrançois, D.; Virgili, J.; Planel, E.; Giguere, Y.; et al. Insulin reverses the high-fat diet-induced increase in brain $\mathrm{A} \beta$ and improves memory in an animal model of Alzheimer disease. Diabetes 2014, 63, 4291-4301. [CrossRef] [PubMed]

85. Mehla, J.; Chauhan, B.C.; Chauhan, N.B. Experimental induction of type 2 diabetes in aging-accelerated mice triggered Alzheimer-like pathology and memory deficits. J. Alzheimers Dis. 2014, 39, 145-162. [PubMed]

86. Cao, D.; Lu, H.; Lewis, T.L.; Li, L. Intake of sucrose-sweetened water induces insulin resistance and exacerbates memory deficits and amyloidosis in a transgenic mouse model of Alzheimer disease. J. Biol. Chem. 2007, 282, 36275-36282. [CrossRef] [PubMed]

87. Li, Z.G.; Zhang, W.; Sima, A.A. Alzheimer-like changes in rat models of spontaneous diabetes. Diabetes 2007, 56, 1817-1824. [CrossRef] [PubMed]

88. Nagai, N.; Ito, Y.; Tanino, T. Effect of high glucose levels on amyloid $\beta$ production in retinas of spontaneous diabetes mellitus Otsuka Long-Evans Tokushima fatty rats. Biol. Pharm. Bull. 2015, 38, 601-610. [CrossRef] [PubMed]

89. Cataldo, A.M.; Nixon, R.A. Enzymatically active lysosomal proteases are associated with amyloid deposits in Alzheimer brain. PNAS 1990, 87, 3861-3865. [CrossRef] [PubMed]

90. Cataldo, A.M.; Barnett, J.L.; Pieroni, C.; Nixon, R.A. Increased neuronal endocytosis and protease delivery to early endosomes in sporadic Alzheimer's disease: Neuropathologic evidence for a mechanism of increased $\beta$-amyloidogenesis. J. Neurosci. 1997, 17, 6142-6151. [PubMed]

91. Cataldo, A.M.; Petanceska, S.; Terio, N.B.; Peterhoff, C.M.; Durham, R.; Mercken, M.; Metha, P.D.; Buxbaum, J.; Haroutunian, V.; Nixon, R.A. A $\beta$ localization in abnormal endosomes: Association with earliest A $\beta$ elevations in AD a syndrome. Neurobiol. Aging 2004, 25, 1263-1272. [CrossRef] [PubMed]

92. Nixon, R.A. Endosome function and dysfunction in Alzheimer's disease and other neurodegenerative diseases. Neurobiol. Aging 2005, 26, 373-382. [CrossRef] [PubMed]

93. Nixon, R.A. Autophagy, amyloidogenesis and Alzheimer disease. J. Cell Sci. 2007, 120, 4081-4091. [CrossRef] [PubMed]

94. Kimura, N.; Inoue, M.; Okabayashi, S.; Ono, F.; Negishi, T. Dynein dysfunction induces endocytic pathology accompanied by an increase in Rab GTPases: A potential mechanism underlying age-dependent endocytic dysfunction. J. Biol. Chem. 2009, 284, 31291-31302. [CrossRef] [PubMed] 
95. Kimura, N.; Okabayashi, S.; Ono, F. Dynein dysfunction disrupts intracellular vesicle trafficking bidirectionally and perturbs synaptic vesicle docking via endocytic disturbances a potential mechanism underlying age-dependent impairment of cognitive function. Am. J. Pathol. 2012, 180, 550-561. [CrossRef] [PubMed]

96. Grbovic, O.M.; Mathews, P.M.; Jiang, Y.; Schmidt, S.D.; Dinakar, R.; Summers-Terio, N.B.; Ceresa, B.P.; Nixon, R.A.; Cataldo, A.M. Rab5-stimulated up-regulation of the endocytic pathway increases intracellular $\beta$-cleaved amyloid precursor protein carboxyl-terminal fragment levels and A $\beta$ production. J. Biol. Chem. 2003, 278, 31261-31268. [CrossRef] [PubMed]

97. Koh, Y.H.; von Arnim, C.A.; Hyman, B.T.; Tanzi, R.E.; Tesco, G. BACE is degraded via the lysosomal pathway. J. Biol. Chem. 2005, 280, 32499-32504. [CrossRef] [PubMed]

98. Lefort, R.; Pozueta, J.; Shelanski, M. Cross-linking of cell surface amyloid precursor protein leads to increased $\beta$-amyloid peptide production in hippocampal neurons: Implications for Alzheimer's disease. J. Neurosci. 2012, 32, 10674-10685. [CrossRef] [PubMed]

99. Harold, D.; Abraham, R.; Hollingworth, P.; Sims, R.; Gerrish, A.; Hamshere, M.L.; Pahwa, J.S.; Moskvina, V.; Dowzell, K.; Williams, A.; et al. Genome-wide association study identifies variants at CLU and PICALM associated with Alzheimer's disease. Nat. Genet. 2009, 41, 1088-1093. [CrossRef] [PubMed]

100. Seshadri, S.; Fitzpatrick, A.L.; Ikram, M.A.; DeStefano, A.L.; Gudnason, V.; Boada, M.; Bis, J.C.; Smith, A.V.; Carassquillo, M.M.; Lambert, J.C.; et al. Genome-wide analysis of genetic loci associated with Alzheimer disease. JAMA 2010, 303, 1832-1840. [CrossRef] [PubMed]

101. Vardarajan, B.N.; Bruesegem, S.Y.; Harbour, M.E.; St. George-Hyslop, P.; Seaman, M.N.; Farrer, L.A. Identification of Alzheimer disease associated variants in genes that regulate retromer function. Neurobiol. Aging 2012, 33, 2231. [CrossRef] [PubMed]

102. Talwar, P.; Silla, Y.; Grover, S.; Gupta, M.; Agarwal, R.; Kushwaha, S.; Kukreti, R. Genomic convergence and network analysis approach to identify candidate genes in Alzheimer's disease. BMC Genom. 2014, 15, 199. [CrossRef] [PubMed]

103. Chouraki, V.; Seshadri, S. Genetics of Alzheimer's disease. Adv. Genet. 2014, 87, 245-294. [PubMed]

104. Okabayashi, S.; Shimozawa, N.; Yasutomi, Y.; Yanagisawa, K.; Kimura, N. Diabetes mellitus accelerates A $\beta$ pathology in brain accompanied by enhanced GA $\beta$ generation in nonhuman primates. PLoS ONE 2015, 10, e0117362. [CrossRef] [PubMed]

105. Lane, R.F.; Raines, S.M.; Steele, J.W.; Ehrlich, M.E.; Lah, J.A.; Small, S.A.; Tanzi, R.E.; Attie, A.D.; Gandy, S. Diabetes-associated SorCS1 regulates Alzheimer's amyloid- $\beta$ metabolism: Evidence for involvement of SorL1 and the retromer complex. J. Neurosci. 2010, 30, 13110-13115. [CrossRef] [PubMed]

106. Iqbal, K.; Alonso Adel, C.; Chen, S.; Chohan, M.O.; El-Akkad, E.; Gong, C.X.; Khatoon, S.; Li, B.; Liu, F.; Rahman, A.; et al. Tau pathology in Alzheimer disease and other tauopathies. Biochim. Biophys. Acta 2005, 1739, 198-210. [CrossRef] [PubMed]

107. Imahori, K.; Uchida, T. Physiology and pathology of tau protein kinases in relation to Alzheimer's disease. J. Biochem. 1997, 121, 179-188. [PubMed]

108. Ishiguro, K.; Omori, A.; Takamatsu, M.; Sato, K.; Arioka, M.; Uchida, T.; Imahori, K. Phosphorylation sites on tau by tau protein kinase I, a bovine derived kinase generating an epitope of paired helical filaments. Neurosci. Lett. 1992, 148, 202-206. [CrossRef]

109. Michel, G.; Mercken, M.; Murayama, M.; Noguchi, K.; Ishiguro, K.; Imahori, H.; Takashima, A. Characterization of tau phosphorylation in glycogen synthase kinase- $3 \beta$ and cyclin dependent kinase- 5 activator (p23) transfected cells. Biochim. Biophys. Acta 1998, 1380, 177-182. [CrossRef]

110. Godeman, R.; Biernat, J.; Mandelkow, E.; Mandelkow, E.M. Phosphorylation of tau protein by recombinant GSK3ß: Pronounced phosphorylation at select Ser/Thr-Pro motif but no phosphorylation at Ser ${ }^{267}$ in the repeat domain. FEBS Lett. 1999, 454, 157-164. [CrossRef]

111. Hanger, D.P.; Hughes, K.; Woodgett, J.R.; Brion, J.P.; Anderton, B.H. Glycogen synthase kinase-3 induces Alzheimer's disease-like phosphorylation of tau: Generation of paired helical filament epitopes and neuronal localisation of the kinase. Neurosci. Lett. 1992, 147, 58-62. [CrossRef]

112. Ullrich, A.; Bell, J.R.; Chen, E.Y.; Herrera, R.; Petruzzelli, L.M.; Dull, T.J.; Gray, A.; Coussens, L.; Liao, Y.C.; Tsubokawa, M.; et al. Human insulin receptor and its relationship to the tyrosine kinase family of oncogenes. Nature 1985, 313, 756-761. [CrossRef] [PubMed]

113. Myers, M.G., Jr.; Sun, X.J.; White, M.F. The IRS-1 signaling system. Trends Biochem. Sci. 1994, 19, $289-293$. [CrossRef] 
114. O'Hare, T.; Pilch, P.F. Intrinsic kinase activity of the insulin receptor. Int. J. Biochem. 1990, 22, 315-324. [CrossRef]

115. Ghasemi, R.; Haeri, A.; Dargahi, L.; Mohamed, Z.; Ahmadiani, A. Insulin in the brain: Sources, localization and functions. Mol. Neurobiol. 2013, 47, 145-171. [CrossRef] [PubMed]

116. Adamo, M.L.; Shemer, J.; Roberts, C.T., Jr.; LeRoith, D. Insulin and insulin-like growth factor-I induced phosphorylation in neurally derived cells. Ann. N. Y. Acad. Sci. 1993, 692, 113-125. [CrossRef] [PubMed]

117. Abbott, M.A.; Wells, D.G.; Fallon, J.R. The insulin receptor tyrosine kinase substrate p58/53 and the insulin receptor are components of CNS synapses. J. Neurosci. 1999, 19, 7300-7308. [PubMed]

118. Werther, G.A.; Hogg, A.; Oldfield, B.J.; McKinley, M.J.; Figdor, R.; Allen, A.M.; Mendelsohn, F.A. Localization and characterization of insulin receptors in rat brain and pituitary gland using in vitro autoradiography and computerized densitometry. Endocrinology 1987, 121, 1562-1570. [CrossRef] [PubMed]

119. Dozza, B.; Smith, M.A.; Perry, G.; Tabaton, M.; Strocchi, P. Regulation of glycogen synthase kinase-3 $\beta$ by products of lipid peroxidation in human neuroblastoma cells. J. Neurochem. 2004, 89, 1224-1232. [CrossRef] [PubMed]

120. Ke, Y.D.; Delerue, F.; Gladbach, A.; Götz, J.; Ittner, L.M. Experimental diabetes mellitus exacerbates tau pathology in a transgenic mouse model of Alzheimer's disease. PLoS ONE 2009, 4, e7917. [CrossRef] [PubMed]

121. Gong, C.X.; Singh, T.J.; Grundke-Iqbal, I.; Iqbal, K. Phosphoprotein phosphatase activities in Alzheimer disease brain. J. Neurochem. 1993, 61, 921-927. [CrossRef] [PubMed]

122. Gong, C.X.; Shaikh, S.; Wang, J.Z.; Zaidi, T.; Grundke-Iqbal, I.; Iqbal, K. Phosphatase activity toward abnormally phosphorylated tau: Decrease in Alzheimer disease brain. J. Neurochem. 1995, 65, 732-738. [CrossRef] [PubMed]

123. Vogelsberg-Ragaglia, V.; Schuck, T.; Trojanowski, J.Q.; Lee, V.M. PP2A mRNA expression is quantitatively decreased in Alzheimer's disease hippocampus. Exp. Neurol. 2001, 168, 402-412. [CrossRef] [PubMed]

124. Tanimukai, H.; Grundke-Iqbal, I.; Iqbal, K. Up-regulation of inhibitors of protein phosphatase-2A in Alzheimer's disease. Am. J. Pathol. 2005, 166, 1761-1771. [CrossRef]

125. Planel, E.; Tatebayashi, Y.; Miyasaka, T.; Liu, L.; Wang, L.; Herman, M.; Yu, W.H.; Luchsinger, J.A.; Wadzinski, B.; Duff, K.E.; et al. Insulin dysfunction induces in vivo tau hyperphosphorylation through distinct mechanisms. J. Neurosci. 2007, 27, 13635-13648. [CrossRef] [PubMed]

126. Clodfelder-Miller, B.J.; Zmijewska, A.A.; Johnson, G.V.; Jope, R.S. Tau is hyperphosphorylated at multiple sites in mouse brain in vivo after streptozotocin-induced insulin deficiency. Diabetes 2006, 55, 3320-3325. [CrossRef] [PubMed]

127. Papon, M.A.; El Khoury, N.B.; Marcouiller, F.; Julien, C.; Morin, F.; Bretteville, A.; Petry, F.R.; Gaudreau, S.; Amrani, A.; Mathews, P.M.; et al. Deregulation of protein phosphatase 2A and hyperphosphorylation of $\tau$ protein following onset of diabetes in NOD mice. Diabetes 2013, 62, 609-617. [CrossRef] [PubMed]

128. Chen, Y.; Zhao, Y.; Dai, C.L.; Liang, Z.; Run, X.; Iqbal, K.; Liu, F.; Gong, C.X. Intranasal insulin restores insulin signaling, increases synaptic proteins, and reduces $\mathrm{A} \beta$ level and microglia activation in the brains of 3xTg-AD mice. Exp. Neurol. 2014, 261, 610-619. [CrossRef] [PubMed]

129. Pedrós, I.; Petrov, D.; Allgaier, M.; Sureda, F.; Barroso, E.; Beas-Zarate, C.; Auladell, C.; Pallàs, M.; Vázquez-Carrera, M.; Casadesús, G.; et al. Early alterations in energy metabolism in the hippocampus of APPswe/PS1dE9 mouse model of Alzheimer's disease. Biochim. Biophys. Acta 2014, 1842, 1556-1566. [CrossRef] [PubMed]

130. Craft, S.; Baker, L.D.; Montine, T.J.; Minoshima, S.; Watson, G.S.; Claxton, A.; Arbuckle, M.; Callaghan, M.; Tsai, E.; Plymate, S.R.; et al. Intranasal insulin therapy for Alzheimer disease and amnestic mild cognitive impairment: A pilot clinical trial. Arch. Neurol. 2012, 69, 29-38. [CrossRef] [PubMed]

131. Claxton, A.; Baker, L.D.; Hanson, A.; Trittschuh, E.H.; Cholerton, B.; Morgan, A.; Callaghan, M.; Arbuckle, M.; Behl, C.; Craft, S. Longacting intranasal insulin detemir improves cognition for adults with mild cognitive impairment or earlystage Alzheimer's disease dementia. J. Alzheimers Dis. 2015, 44, 897-906. [PubMed]

(C) 2016 by the author; licensee MDPI, Basel, Switzerland. This article is an open access article distributed under the terms and conditions of the Creative Commons by Attribution (CC-BY) license (http://creativecommons.org/licenses/by/4.0/). 